\title{
ネグリ小体の電顕的研究
}

\author{
宮本包厚

\section{ELECTRON MICROSCOPIC STUDIES OF THE NEGRI BODY}

\author{
Kaneatsu MIYAMOTO \\ Department of Tumor Virus, Institute for Virus Research, Kyoto University
}

[受付：1月 5 日, 1966]

\section{I. 序}

ウイルス病に好発する種々の細胞内封入体の中, 古く より知られるネグリ小体は狂犬病街上毒ウイルス感染動 物の神経細胞内に特異的に出現し，その内部に好塩基性 顆粒構造（innere Körperchen）を包含せる好酸性細胞質 内封入体である。本小体は Negri(1903) 28)により報告さ れて以来, 他の多くの脳脊髄炎との鑑別診断上の指標と して重要視されて来た. 一方, 街上毒ウイルスは数十代 の脳内継代により固定毒化し，ネグリ小体形成能を失う と共に，固定毒ウイルスに特徴的な諸性質を示すに至 る. 街上毒ウイルスの脳内継代により惹起された，斯る 顕著な細胞内反応様式の変化は他のウイルスに例を見な い現象である。しかも，同小体の重要な構成因子である innere Körperchen は他のウイルス病に出現する封入体 に認められない構造物として特異的である。斯る観点よ り, 同小体の本態に関しては細胞病理学执よびウイルス 学的興味より過去 60 余年に渉り, 病理組織学的, 細胞 物理化学的あるいは電顥形態学的に多くの研究が行わ れ, 諸説が提唱されて来た.

\section{ネグリ小体研究の歴史的概観}

ネグリ小体の本態に関する多くの研究を Protozoa 説, ウイルス粒子集団説，神経細胞小器官由来説および神経 細胞二次産物説に分ち簡単に記すと共に問題点を示す.

1) Protozoa 説

ネグリ小体の見出されたのは今日の “ウイルス” と いう概念が確立される以前であつて (1903)，この頃に前 後して “濾過性病原体”の発見が続出する時代となつ た. Remlinger ${ }^{33}$ )が狂犬病病原体の濾過性を証明したの は同じく 1903 年である. 当時の学問的背景より見れば, Negri を始諸家の論文に記載された“Strassenvirus”, 或は “Virus fixe” と云う言葉は具体的対象物を指す ものではなく, 単に漠然とした“病毒”と云う概念で

京都大学ウイルス研究所癌ウイルス部
用いられていたものと思われる. 従つて, Negri ${ }^{28}$ が狂犬 病街上毒 “ウイルス” 感染神経細胞に出現する好酸性 封入体を形態学的類似性より Protozoa と見做し, これ を狂犬病の病原体と考えたのも当時としては無理からぬ ことであろう。

Williams 等(1906) ${ }^{42)}$ は更に進んでネグリ小体が Sporozoa に属すると考え同小体の生活環に就いて記載した が，この頃にはネグリ小体が Protozoa の何れに属する かが論点となつた。

Levaditi 等(1924, 1926) ${ }^{15) 16)}$ は狂犬病病原体の濾過性を 考慮しながら Protozoa としての生活環を提唱した. 彼等 は狂犬病病原体が Microsporidium であり, 宿主細胞内で 二相の生活環を有すると考えた. 即ち spore の時期が濾 過性且つ非可視性であり (La phase ultra-microscopique), 咬傷部より中枢神経系に至ると共に細胞内増殖を生じ Pansporollast 或はネグリ小体を形成する (La phase pansporoblastique). 従つて, innere Körperchen は spore の集団であり，好酸性基質はその外被と見做した。

ネグリ小体を斯る Protozoa の生活環の一形態とする 立場は Ssawatezew 等 (1929) ${ }^{37)}$, Muratowa(1934)27) あ るいは Shortt (1935) 35)等により支持された. Shortt は 感染の経過と共にネグリ小体が大型化し，かつ他のウイ ルス病に見られる封入体に比し生物学的構造 (organized entities) を有する点に注目し, Protozoa の発育の全ゆる 段階を示すものとして同小体の種々の形態を詳細に観察 した。

しかしながら, ウイルス学の確立した現在, Protozoa 説を信ずる者は全くいないと思われる.

2）ウイルス粒子集団説

19 世紀末より始つた“濾過性病原体”の発見は多く の研究者を細菌あるいは parasite 等既知の病原体以外 の，目に見えない未知の病原体の探求へと駆り立てた。

狂犬病に関して言えば, Volpino(1906) ${ }^{40)}$ は狂犬病の parasite(病原体)がネグリ小体内部の innere Körperchen 
内に存在すると述べているが，彼はすでに狂犬病病原体 の濾過性抢よび非可視性を認識していた。, 一方, Babes $(1907)^{33}$ は $0.1 \mu$ の小桿菌を濾過する濾過器が狂犬病病 原体を通過させないといら彼自身の経験に基づき，同病 原体の大きさが $0.1 \mu$ より余り小さくないと述べると共 に存在場所を同じく innere Körperchen に求めた. その 際, 両者共ネグリ小体の好酸性基質の成因を病原体感染 に基づく細胞反虑産物と考えた。

細胞内封入体を基礎化してイルス・宿主細胞関係の 概念をウイルス学に導入したのは Prowazek(1907) ${ }^{31) の ~}$ Chlamydozoa 説である。すなわち, 彼は狂犬病も含め特 異的に細胞質内封入体を形成する疾患注目し，当時見 出されていた封入体疾患全ての病原体を Chlamydozoa の名の下に統一した. 斯る Chlamydozoa は滤過性かつ 非可視性で宿主細胞内で増殖する性格を持つ。さらに， Chlamydozoa の侵入 (Invasion) を受けた宿主細胞は核 物質様あるいはプラスチン様反応産物を産生し, これが Chlamydozoa を包含して封入体を形成する. 彼は白血 球内に認められる細菌は貧喰作用に基づくものであると し, Chlamydozoaの侵入と区別して考光た。しかし，当 時認められていた封入体疾患全てを統一した為に猩紅熱 に見られる Mallory 小体をも含めていた。斯る概念は Lipschïtz (1919) 17) に受け継がれ今日のウイルス・宿主 細胞関係の確立に影響を与えたと考えられる。

その後顕著な研究を認め得なかつたが, 細胞化学の進 展に伴い, その方法はこの分野にも導入されるに至つ た, Wolman 等(1952) ${ }^{43}$ 注ウイルス封入体がウイルス粒 子の集団であり, 封入体発育の過程に抢いてウイルス素 材およびこれに関連した酵素活性が急速に増加するもの と考えた. 彼等は殆んどの動物ウイルスが DNP（デオキ シ核蛋白）を含有すると仮定して，まずへルペス・ウイ ルス感染鷂胚漿尿膜に出現する核内封入体を細胞化学 的に経時的検索を行つた。 核内封入体の DNP 含量は 封入体容積の増大に伴いかつ好塩基性に平行して増加 し, さらに lipase 抢よび cholinesterase 活性の上昇を 認めた。 その後封入体が好酸性になると共に DNP 含量 抢よび酵素活性法減少した。一方街上毒ウイルス感染脳 で同様の検索を行つた ${ }^{44)}$. 接種 1 日後に Feulgen 反応 陽性の小型好塩基性封入体を認めるが，該封入体注大き さを増すと共に Feulgen 反応陰性基質で包埋され，同 時に数を增した. 6 日後には該封入体はさらに大となり 均一な好酸性封入体 (Lyssa body 後記) に移行し, Feulgen 反応陰性を示した。一方上記酵素活性は該封入体の Feulgen 反応陽性性 および好塩基性と平行して消長し た. 斯る知見より, 彼等はネグリ小体がヘルペス封入体
と同じくウイルス粒子を含有し，ウイルス粒子が封入体 内部で增殖して最高に達した後粒子の減少を来すものと 考えた.

近年のウイルス学に打ける螢光抗体法の寄与は多大で ある. 本法をネグリ小体研究に応用したのはGoldwasser 等 $(1958)^{9)}$ であつた。彼等はネグリ小体陰性狂犬病罹患 動物の診断法として街上毒ウイルス感染脳安門角のスタ ンプ標本に本法を用いた結果, ネグリ小体が螢光陽性で あることを明かにし，同小体がウイルス抗原を含有する ことを示唆した.

3) 神経細胞小器官由来説

Prowazek の Chlamydozoa 説に端を発し, ウイルス・ 宿主細胞関係の概念がネグリ小体の本態解明の一方向と して取り入れられたものの様である。すなわち, ウイル 又感染に基づく細胞内反応が重視され, 同小体が神経細 胞に特異的に出現しかつ細胞変性像を一般に認めない点 より，ネグリ小体形成には変性した細胞物質よりも寧ろ 細胞小器官の関与に注意が向けられた。

\section{i) 核小体由来}

砒素中毒あるいは狂犬病以外の疾患でネグリ小体類 似の好酸性封入体が認められることより, Acton 等 (1911)11) はまずネグリ小体の特異性を検討した。彼等は 蝮蛇毒, コブラ蛇毒, 破傷風毒素, B. pyocyaneus 生菌 浮遊液および正常犬脳物質を動物に接種し, 蝮蛇毒（モ ルモット), 生菌(家躳) および正常犬脳物質接種脳に小 数ながらネグリ小体類似の封入体を認めた. 従つて, ネ グリ小体が狂犬病に特異的でないと結論し, 次いで同小 体が parasite であれば如何なる動物においてもその構造 および発育形態が類似するとの想定の下に 10 種類におよ ぶ哺乳動物を実験対象とした。 その結果，牛では 4 ない し $20 \mu$ のネグリ小体を多数認めたが，人間では少数で 1 ないし $6 \mu$ ，家鬼では 2 ないし $5 \mu$ であつた。斯様に ネグリ小体の形, 大きさ扔よび染色性が異種動物で異る のに対し, 同種動物では斯る性質は恒定であった（類似 の所見を後記の Lentzも認めた)。さらに大型ネグリ小 体を形成する感染牛細の浮遊液を小型同小体を形成する 家鬼に接種すると，出現する同小体は全て小型で家鬼に 特徴的な形態拉よび染色性を示した。斯る知見より彼等 はネグリ小体の形態はウイルスによつて左右されるので はなく, 細胞反応の関与の下に接種動物の種類により異 り, 従つてネグリ小体は同一の病原体から成るとは考え 難いと結論した.

上記検索に基づき，彼等はネグリ小体の本態を核小体 に求め, Antedon bifida の卵母細胞発育過程に見られる 核小体より卵黄核への移行, さらに膵臟細胞めるいは病 
的細胞における核小体と細胞質との関係をネグリ小体形 成様式に引用した。 すなわち, 核小体物質はある条件下

(ネグリ小体の場合狂犬病ウイルス感染に基ずく新陳代 謝の変化）で完全に細胞質に 押し出されるか (extrude) あるいは断裂して(狂犬病家鬼脳で核小体の断裂が著 明)，乙机等が細胞質に移動し，一方核小体自身は元の 形態に複帰する. 細胞質内に放出された核小体由来顆粒 は完全に消失するかあるいは膨化，融合しかつ細胞質と 混合して細胞質内構造物（ネグリ小体）を形成する. 核 小体由来顆粒が核周辺部に存在する場合核物質性染色態 度を示すが，核より離れるとこの染色態度を失うことよ り，核小体物質が直接ネグリ小体に転換するのではなく 該物質と細胞質との間の相互作用 (interaction) により 間接的に形成されるものと考えた。

\section{ii）神経細線維由来}

Goodpasture (1925) 10) は狂犬病街上毒ウイルスの末梢 部より中枢神経系に至る感染経路を家鬼で研究中, ネグ リ小体の他に innere Körperchen を包含せ好小体類似 の小型好酸性細胞質内封入体を見出した。これは時にネ グリ小体と共に神経細胞内に併存した。 以前より, 小型 ネグリ小体で innere Körperchen の認められない場合が あつたが，その原因は該構造の染色が困難な為と考えら れていた。ネグリ小体の本態に関する理論的および診断 的重要性より, 彼は斯る封入体をネグリ小体の定義に合 致しないものとして “Lyssa body” と命名し, 同小体 と厳密に区別した上で両者の形成過程を明かにしょうと した.

街上毒ウイルスを咬筋に 接種した場合, 脳橋部特に Deiter 氏核の神経細胞にネグリ小体および Lyssa body が存在する他, 神経細線維の変性像を認めた. すなわち 多くの神経細胞に壊死像が見られると共に神経細線維由 来と考えられる小線維が網状構造あるいは大小の凝集像 を示し, 円形ないし棈円形の構造物を形成した。 この構 造物の染色性は Lyssa body と同一であつた. しかし, 神 経細線維の変性により生じた封入体には innere Körperchen は存在しなかつた。一方, carbol anilin fuchsin 法 で正常神経細線維は染まらないが，上記の変性した神経 細線維は fuchsin で強染性である為に, 彼は神経細線維 物質がウイルスの影響によりネグリ小体の好酸性物質あ るいは Lyssa body と同性質の封入体に転換されるので あろうと考えた。しかし，この様な変化の見られる細胞 は壊死性でありかつ神経細線維物質の全てが変化するの で，形成された封入体は生きた細胞に見られる封入体と 異ると述べ, Lyssa body の形成は細胞内の一局所の神 経細線維物質の変性に基ゔくと考えた. 一方, ジステン
バーあるいは鶏ペストで類似の封入体が認められること より, 神経細線維の変性に基づく Lyssa body の形成は 狂犬病ウイルスに特異的でないと考えた。

神経細線維の硝子様構造への転換だけでは innere Körperchen の存在する典型的なネグリ小体の形成過程 を説明し得ないので, 彼は糸粒体の変化に着目した。す なわち，糸粒体は大きさおよび数を増すが，傷害の程度 が強いと非常に減少し種々の変性像を示した。系粒体は 空胞化し辺縁部好酸性を示し, 内部に好塩基性顆粒 を認めた。系粒体に変性像の見られる細胞には小型の Lyssa body が多数認められたが，壞死像は見られなか つた：彼は糸粒体が種々の因子特にウイルスにより影響 を受け易いと考元, 上記の変性像が他に例を見ないこと より，狂犬病ウイルスに特異的な現象と見做した. 以上 の知見に基づいて，彼は innere Körperchen を含む典型 的なネグリ小体はウイルス作用により特異的に膨化変性 を来した糸粒体と細胞質一局所に生じた神経細線維変性 物質とが癒合して形成されると考えた。

現在, Lyssa body は広義のネグリ小体の範疇に大る ものと考光られている39.

\section{iii）ニッスル小体および核物質由来}

Covell 等 $(1932)^{4)}$ は細胞小器官特殊染色法あるいは細 胞化学的方法により生細胞および固定細胞でネグリ小体 の本態を解明しようとした。ネグリ小体に個有の膜構造 が認められず，また暗視野で innere Körperchen の運動 性を認めなかつた。さらにネグリ小体に対する Feulgen 反応の結果が不定であつた。これ等の点よりネグリ小体 が Protozoa であるとは考え難く, 寧ろ 同小体内に核由 来のクロマチンが存在することを示唆するものと考え た. 従つて, 彼等はネグリ小体が正常神経細胞に存在す る細胞成分より形成されると想定した. microincineration および Feulgen あるいは Millon 反応で核物質が innere Körperchen に認められた。ささらに, 狂犬病感染神経細 胞で鉄含有好塩基性クロマチンが好酸性顆粒に転換した が，この顆粒の鉄含有量は非常に少なく，かつ該顆粒 が本来ニッスル小体のあるべき場所に存在するという知 見を引用し，次の結論に至つた。すなわち, chromatolysis 抢よびこれに伴つたニッスル小体の変化をもたら すような反応がウイルスの作用により生ずる．核の好塩 基性鉄含有蛋白が適当な核・細胞質内比率を維持しょう として細胞質に遊出し，これが細胞反応を受けながら徐 々に好酸性となり，ネグリ小体の均一な基質物質に変化 する. 変化を受けない蛋白の残部が 鉄含有好塩基性の innere Körperchen を形成する. Lyssa body は好塩基性 クロマチンの全てが完全に好酸性物質に転換されるか女 
るいは chromatolysis の間に鉄含有性を失つたニッスル 小体の変化した 粒子の集合によつて生ずるものと考え た.

\section{4) 神経細胞二次産物説}

Lentz (1909)14) i innere Körperchen が狂犬病病原体で ないと述べると共に，同小体研究の一側面として固定毒 ウイルス感染家躳脳抢よびジステンバー罹患犬脳を検索 し，それぞれ Passagewutkörperchen (Lentz body) およ びStaupekörperchen を認めた. 三者の比較検討により, 彼の細胞二次産物説はさらに強められ，ネグリ小体は病 原体が神経細胞に変性を惹起せしめる過程で生ずる該細 胞の反応産物であると考えた。なお Lentz body は家鬼 安門角の神経細胞閒部に認められ，その形態はネグリ小 体に類似する。しかし，出現部位が細胞外でネグリ小体 より可成り大である，彼は Lentz body が変性過程にあ る神経細胞核由来と考えたが，現在なおその本態は明か でない。

d'Amato 等 (1910) ${ }^{6}$ は同じくネグリ小体は病原体とは 無関係で，本質的には病原体感染に基づく細胞反応の結 果生じた変性産物と考えた。

Hottle 等 (1951) 12) は後記するごとく電顕形態学的に 同小体が電子密度の 高い無構造 な 細胞質内封入体であ り，ウイルス粒子を認めないと述べた。

Sourander (1956) ${ }^{36)}$ はウイルス粒子が可成りの量の核 蛋白を含有し，またウイルス感染細胞で宿主細胞の蛋白 および核酸量の変化が生ずることを考慮して，ネグリ小 体と周囲細胞質の蛋白分布および同小体内での核酸の出 現を細胞物理化学的に検索し同小体の本態を明かにしよ うとした。一般にネグリ小体は X-ray microautoradiography で調ベると周囲細胞質より多くの蛋白を含有し た。紫外線 spectrography では RNase および DNase 注共に innere Körperchen あるいはネグリ小体基質吸収 像に影響せず，さらに，RNase およびDNase 消化後の Mann 氏染色で同小体基質掞よび innere Körperchen は それぞれ好酸性および好塩基性を示した. 以上の点より， 彼はネグリ小体には RNA も DNA も存在しないと結論 し, 同小体はウイルス粒子より構成されるのではなく,街 上毒ウイルス感染に対する細胞質反応を示すと考えた．

われわれも後記するごとく，ネグリ小体がウイルス増 殖部位とは別個の，ウイルス感染による細胞二次産物で あるとする立場をとつて来た。

ネグリ小体の本態に関する最近の論議は 1) 同小体が ウイルス粒子を包含するか否か，2）ウイルス感染に基 づく細胞反応の結果生ずる細胞二次産物か否かという問 題にしぼられて来た。これ等諸点の解明には，現在電顕
的検索法が最も有力と考えられる。しかしながら，中枢 神経系に捻けるネグリ小体出現部位が限定され，しかも 好発部位の一つである安門角においてさえ全ての神経細 胞に必発するわけでなく，同小体の微細構造を直接電顕 下に観察するのは技術的に容易でなかつた，最近，狂犬 病ウイルス感染脳13720)21)34) および培養細胞2)7》に打ける 同ウイルス粒子の形態执よび増殖様式が電顕形態学的に 明かにされるにおよび，ネグリ小体の形態をウイルス増 殖像と関連して検討し得る段階に達つした

われわれは既報25)のごとく，狂犬病街上毒ウイルス感 染マウス脳より安門角神経細胞層の超薄切片およびこれ に連続する厚い切片(約 $1.0 \mu$ ) を作製し，ネグリ小体を 光顕及び電顕形態学的に比較検索し，同小体がウイルス 増殖と密接に関連したマトリックス域そのものであり, さらに innere Körperchen がウイルス粒子および細胞質 成分より構成されることを明かにした。本論文に掞いて は，同小体の形態をさらに詳細に報告すると共に， innere Körperchen の形成様式およびネグリ小体形成能 について考按する.

\section{II. 材料および方法}

使用ウイルスは農林省家畜衛生試験場佐沢博士より分 与された狂犬病街上毒ウイルス小松川株である。本株ウ イルスは狂犬病罹患犬の脳乳剤をモルモット下肢に接種 し, その後該動物 脳乳剤の下肢 19 継代後, マウス脳内 継代により維持されており, 高いネグリ小体形成能を示 す為本研究目的に好都合な接種材料である。

生後 5 日ないし 6 日の幼若マウス脳内に上記小松川株 ウイルス（マウス脳内 1 継代）を $10^{3} \times \mathrm{LD}_{50}$ 程度の浮遊 液として接種した。接種後 8 日ないし10日で該動物は 興奮状態となり，翌日典型的な麻痗症状を示した。この 時期に安全カミソリ刃を用いマウス頭中央部にて頭蓋骨 と共に脳を切断し, 速かに脳断端を $5.4 \mathrm{mg}$ glucose $/ \mathrm{ml}$ を含む $2 \%$ 燐酸緩衝オスミウム酸溶液 ${ }^{23}$ に浸し，直ちに 同固定液中で安門角附近組織を 1 ないし $3 \mathrm{~mm}^{3}$ 程度の 小片とし，新鮮な該固定液にて 2 時間室温で固定した. 2 時間を越えるアルコール脱水後, Epon 812 で包埋し た ${ }^{18)}$.この際，春秋抢よび冬期は $\mathrm{A}: \mathrm{B}=1: 4$ とし, 梅雨期より夏期は $\mathrm{A}: \mathrm{B}=1: 8$ とした.

一方，脳残部を $10 \%$ ホルマリン溶液，アルコールある いは Zenker 氏液で固定後, パラフィン包埋した. パラフ イン切片には Mann 氏法あるいは Massignani 氏法 ${ }^{19}$ に よるネグリ小体特殊染色あるいは H-E 染色を行つた.

Epon 包埋組織片における安門角神経細胞層の同定を 容易ならしめる為, せいぜい 3 ないし 4 枚の超薄切片が グリッド上に載る程度の面積に該ブロックを切り込ん 
だ. 電顕と光顕の比較検索に供する超薄切片およびこれ に連続する約 $1.0 \mu$ の厚い切片 (以後 $1 \mu$ 切片と記す) は該ブロックより Porter-Blum ミクロトームを用い，ガ ラスナイフにて作製した. 前者には醋酸鉛染色 24 ) , 後 者には toluidine blue 染色 $\left(\mathrm{pH}\right.$ 11.1) ${ }^{38)}$ を行つた。後者 の場合， $1 \mu$ 切片をスライドグラス上に載せ，火焰に て 10 秒前後加温, 付着せしめ, 直ちに該染色液にて切 片を覆い，色調を見ながら数秒ないし数分間染色を行つ た。原法に基づく脱色は行わなかつた。

広い面積の安門角神経細胞層を示す為, $1 \mu$ 切片によ る光顕地図および超薄切片による低倍率電顕地図を作製 した，後者の場合，直接倍率 3,000 倍を用いた。 使用電子顕微鏡は日立 HU- 11 M 型である.

\section{III. 成 績}

1. パラフィン切片による観察

第 1 A図は Zenker 氏液固定後, H-E 染色を行つた安 門角神経細胞層を示す. 殆んど全ての神経細胞細胞質内 に 1 ないし数個の均一な好酸性基質より構成されるネグ リ小体を認める．同小体は円形ないし楕円形で種々の大 きさを示し，特に大きな同小体の中心部あるいは辺縁部 に好塩基性顆粒構造 (innere Körperchen) が認められ典 型的なネグリ小体の形態を示寸 (第 1 в図). ネグリ小体 と細胞質の境界部に，殆んど染色性を示さない halo の 認められるものもある. 斯る holo はアルコール固定の 場合に顕著に認められた。なお神経細胞内にネグリ小体 以外の病理形態学的変化を認め得なかつた.この同一脳 より電顕用切片を作製した。

2. Epon 包埋 $1 \mu$ 切片による観察

第 2 図は Epon 包埋ブロックより超薄切片に連続して 作製し, toluidine blue 染色を行つた1 門角神経細胞層の光顕地図である. 該切片に H-E 染色 あるいはネグリ小体特殊染色を試みたが成功しなかつ た. 各神経細胞は相互に隣接集合し層状配列を示す。そ れぞれ 1 個の核を有し，核周囲に核膜が明瞭に認められ る，核質は均一な構造で淡染性である，核の内部に 1 な いし数個の濃染性を示す核小体を認める. 細胞質はニッ スル小体の存在の為中等度の染色性を示す.

これ等神経細胞層の顕著な所見は，殆んど全ての神経 細胞に核よりも染色性の乏しい細胞質内封入体の認めら れることである(知印).これ等封入体は種々の大きさで, 一般に円形ないし棈円形を呈し，内部構造は均一な基質 より構成され，その周囲に膜構造あるいは halo 注認め られず周囲細胞質と鋭利に境界されている．さらに該封 入体内部，特に大きな封入体内部に種々の大きさの 1 な 、し数個の顆粒構造を認める。該構造核小体と同程度
に濃染性である。上記形態学的所見より，細胞質内封入 体を核と誤認する可能性は全くない. 細胞質内封入体の 出現頻度は第 1 図に見られるネグリ小体の出現頻度と同 程度と思われる.さらにこれ等構造以外に何等の病理形 態学的変化も神経細胞内に認め得なかつた。

\section{3. 電子顕微鏡による観察}

第 3 図は $1 \mu$ 切片(第 2 図) に連続する超薄切片による 低倍率電顕地図で，第 2 図の枠内に一致する部分の神経 細胞層を示す．それぞれの細胞の形態学的位置関係は両 図において良好な一致を示す。隣接した 4 個の典型的な 神経細胞が認められる。すなわち，核は比較的大きく楕 円形ないし円形で核小体を包含する。細胞質にはニッス ル小体に該当して豊富な疎面小胞体が規則的あるいは不 規則な配列を示し，さらにロゼッテを形成して広沉な分 布を示す多数の遊離リボゾーム顆粒を認める。種々の割 面を示す発育良好なゴルジ体が散在し, 多数の系粒体が 分布している.

これ等神経細胞細胞質内に中等度の電子密度を持つた 均一な基質より成る領域を認め得る。斯る領域は種々の 大きさの円形ないし棈円形を呈し, 細胞膜近くに偏在す る傾向を持つ. 同一細胞内に該領域が 3 個存在する場合 も認められる。これ等領域は細胞質と置き換りその周辺 部に膜構造は認められず，周囲細胞質と鋭利に区別され る. 時に電子密度の高いウイルス粒子が細胞成分と関連 して周囲細胞質あるいは該領域内部に認められる(矢印) 細胞内における形態学的関係より,これ等領域は連続 $1 \mu$ 切片 (第 2 図) に見られる細胞質内封入体と同一構造物と 考え得る. 第 4 図は第 3 図で枠内に示した部分の高倍率 電顕像である。第 3 図において細胞質内に認められる中 等度の電子密度を持つた均一な基質より成る領域は細顆 粒ないし細線維状基質より構成され(第 4 図), 諸家 ${ }^{277}$ 13)20121344の報ずるごとき狂犬病ウイルス感染細胞に出現 するマトリックス域と電顕形態学的に同一構造である.

第 5,6 および 7 図は安門角皮質神経細胞内のマトリッ クス域を示す。われわれは既報22)のごとく狂犬病ウイ ルスの棒状粒子をその電顕像より形態学的に 3 型に分 つた.すなわち，I 型粒子は幅 120 ないし $130 \mathrm{~m} \mu$ の一 重膜構造粒子で, 内部構造は周囲マトリックス基質に類 似し，時に粒子の内部に一枚の限界膜で囲まれやや電子 密度の高い構造を認める (第 5 図). 第 6 図に示す粒子は II型粒子で幅 100 ないし $110 \mathrm{~m} \mu$ の二重膜あるいは横断 面に明かなごとく三重膜構造粒子である。内部は一般に マトリックス基質に比しやや電子密度が高い.マトリッ クス域に近く神経細線維が見られる。これ等 I 型および II 型粒子は常にマトリックス基質部に局在する. III型粒 子は第 5 図に見られるごとくマトリックス域周辺部の桩 
大した小胞体腔内に局在し, 種々の割面を示寸電子密度 の高い棒状粒子として認められる。幅 80 ないし $90 \mathrm{~m} \mu$ の二重膜構造粒子でその外側限界膜梳胞体膜と連続的 な移行を示す (矢印). 以上三種類の棒状粒子の他に，時 にマトリックス基質部に電子密度の高い二重膜構造小 片, 時には II 型粒子類似の構造を認める (第 7 図). 以後 ウイルス粒子の形態に関しては上記分類に従つて記す.

安門角神経細胞層に出現するマトリックス域は一般に 大きく比較的規則的な円形ないし棈円形を示す．これ等 マトリックス域は細胞内に散在性 (第 3 図) あるいは数個 が互いに隣接して（第 4，8，12，13 図）認められる。特 に大きなマトリックス域は一般に単独に存在し，乙かも 不整形で辺縁部に屡々半円形の突出部を認め, 細胞質が 該域内部に向って彎入している(第 $9 ， 11$ 図)。時には長 径が $18 \mu$ に達するものも見られた。

これ等マトリックス域と関連したウイルス粒子は該域 内部あるいは周辺部の小胞体腔内に認められる(第 3,4 , 8〜11 図). 第10図はマトリックス域内部ウイルス粒子 の高倍率電顕像である。第 $10_{\mathrm{A}}$ 図において，マトリック 又域内部に該域基質と劃然と区別されて細胞質基質が見 られる。遊離リボゾーム顆粒と共に少量の疎面小胞体お よび滑面小胞体が認められ，桩大した小胞体腔内に種々 の割面を示す電子密度の高い棒状粒子が多数混在する。 横断面は円形で二重膜構造を明瞭に認める (矢印)。両外 側限界膜は小胞体膜に連続的に移行し，粒子の一端は周 囲マトリックス基質に開放し，他端を小胞体腔に開放す る. しかし, 両外側限界膜が小胞体腔の一部を形成し, 一端をマトリックス基質に，他端を細胞質に開放した 棒状粒子も認める。乙れ等粒子の形態抢よび小胞体との 形態学的関係はマトリックス域周辺部に見られるIII型粒 子(第 5 図) と一致する. 第 $10 \mathrm{~B}$ 図に少量の細胞質基質と 共にリボゾーム顆粒が集合性に認められ，これに近く三 重膜構造の明瞭なウイルス粒子横断面が見られる。最 外側膜㧍よび中間膜で囲まれた部分は高い電子密度を示 し，II型粒子と考え得る. しかし，最外側膜は粒子の二 カ所で互に平行した膜構造へと移行し，一端はマトリッ クス域内の細胞質に連る。

安門角神経細胞層に出現するマトリックス域内部で, 上記のごとく該域基質と劃然と区別して認められるウイ ルス粒子および細胞質成分より構成される構造 (第 3,4 , 8 11 図）は，前報25) 亿明かなごとくネグリ小体に特徵 的な innere Körperchen と考え得る. 従つて, 以後の記 述に際し該構造を電顕的 innere Körperchen と記す。電 顕的 innere Körperchen はマトリックス域内部で種々の 形態を示すが，同一マトリックス域内に認められる数は 一般に少ない，さらに上記構造の他ウイルス粒子を含ま
ない場合も認められる。すなわち，第 12 図に見られる innere Körperchen はリボゾーム顆粒および中等度の電: 子密度を 持つ膜構造と共に電子密度の高、二重膜構 造，時には集合性のリボゾーム顆粒より成る。第 13 図 では少量のリボゾーム顆粒㧠び電子密度の高い小空胞. が見られるに過ぎない，時には innere Körperchenの見 られないマトリックス域（第 3，12，13 図）を認めた。 第 9 抢よび 11 図は大型マトリックス域を示す. 上記マ トリックス域とは対照的に内部に多数の散在性 innere Körperchen を認め，かつその構造は常にウイルス粒子 と細胞質成分の両者を同時に包含している. 大型マトリ ックス域に見られる innere Körperchen の特徴的構造は 該域周囲細胞質と innere Körperchen が屢々連続性を維 持する点である (第 9,11 図)。なお一般に, innere Körperchen 内部に認められるウイルス粒子はマトリッ クス域外側周辺部に存在する粒子に比し高密度に分布す る傾向がある(第 4，8，9，11 図）。

安門角神経細胞層に見られるマトリックス域で該域基 質部に出現するウイルス粒子は稀で，一般に小型マトリ ックス域に認められる傾向がある。例えば，第 8 図にお ける右側マトリックス域基質部に II 型粒子が 1 個見ら れ，第11図に扔いては大型マトリックス域と共存して, その上部の互に隣接した数個の小型マトリックス域基質 部に種々の形態を示す二重膜構造小片および I 型粒子類 似の構造を認內る。

神経細胞には発達したゴルジ体が多数認められる（第 3図). マトリックス域近くのゴルジ体には屡々ゴルジ 囊および空胞の拡大, さらにゴルジ小胞の増加が認めら れる(第 $4,12,13$ 図)。乙れ等小胞はゴルジ䨞とマトリ ックス域の間の細胞質に連続的に多数分布し，その内部 は囲周細胞質基質に比し高、電子密度を示す（第 4，12， 13 図)。時には斯る小胞はマトリックス域を取り囲んで (第 13 図)，あるいは該域基質部(第 10，12，13 図）にも 認められる。

\section{IV. 考 按}

ネグリ小体の本態解明手段として電顕的方法を初め て応用したのは Reagan 等 (1950) ${ }^{32}$ である. しかし, 試料がスタンプ標本である為, その電顕像より同小体の 形態を窥い得ず，いわば過渡的な報告に止まっている。 一方, Hottle 等 (1951) ${ }^{12)}$ は光顕抒よび電顕形態学的検 索法の併用を試みた。すなわち，フォルマリン固定パラ フィン切片でネグリ小体を確認後, 脱パラフィンし, 電 顕用にメサクリレートで再包埋して超薄切片を作製し た。 その結果, 同小体が電子密度の高、無構造な細胞質 内封入体であり，その内部あるいは周囲細胞質内にウイ ルス粒子を認めないと報告し，方法論的に注目された。 


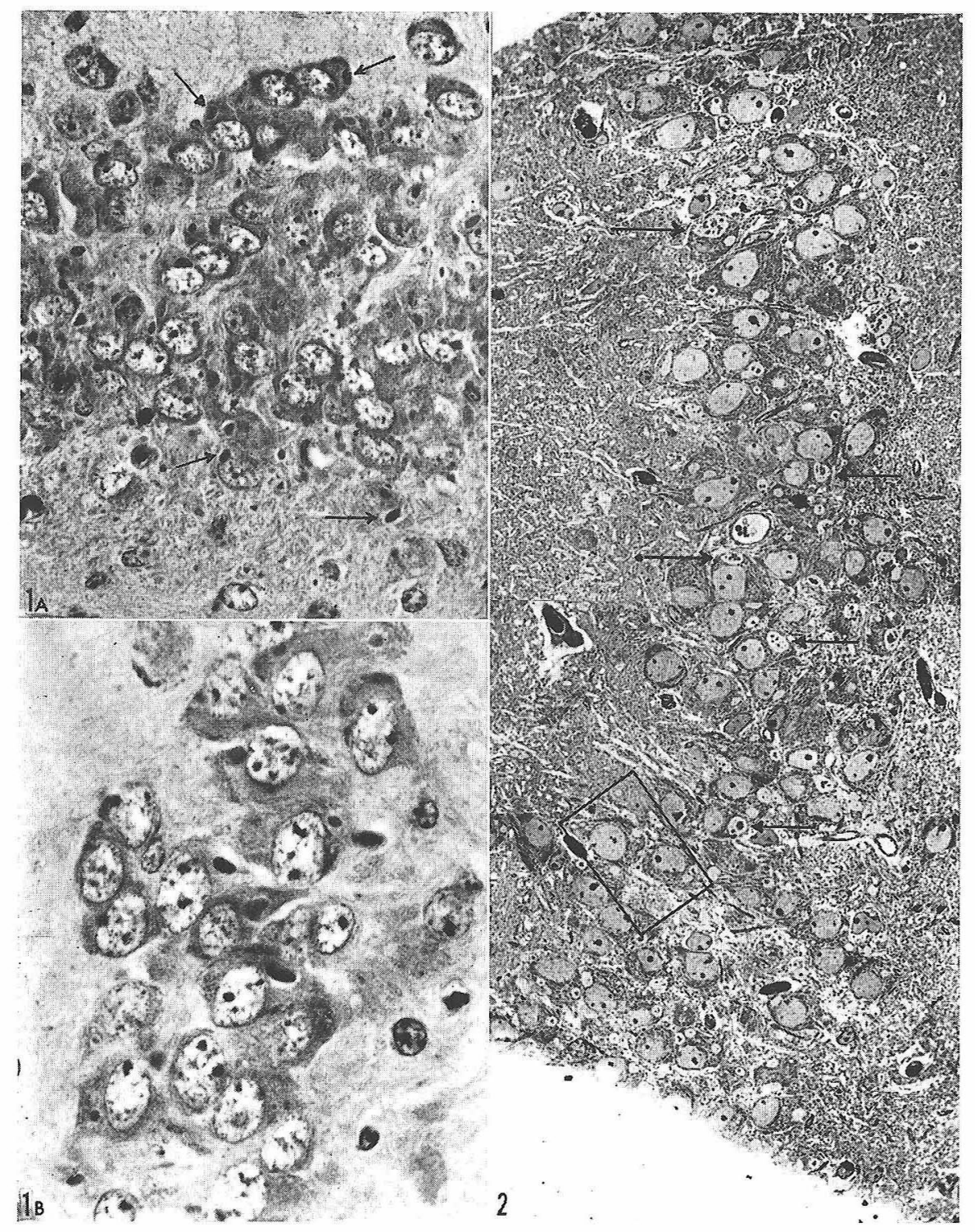

Fig. 1. A) A light micrograph of Ammon's horn in the mouse hippocampus after hematoxylin-eosin staining. Many Negri bodies varying in size are found within nearly all of nerve cells. Several representative Negri bodies are indicated by arrows. X 320

B) Some typical Negri bodies at higher magnification. X 620

Fig. 2. A light micrograph of a section of Epon-embedded hippocampus, stained by toluidine blue solution. Nerve cells, most of which contain lightly stained cytoplasmic inclusion bodies, are closely packed. Several representative inclusion bodies are indicated by arrows. An electron micrograph of the rectangular area is shown in Fig. 3. X 270 


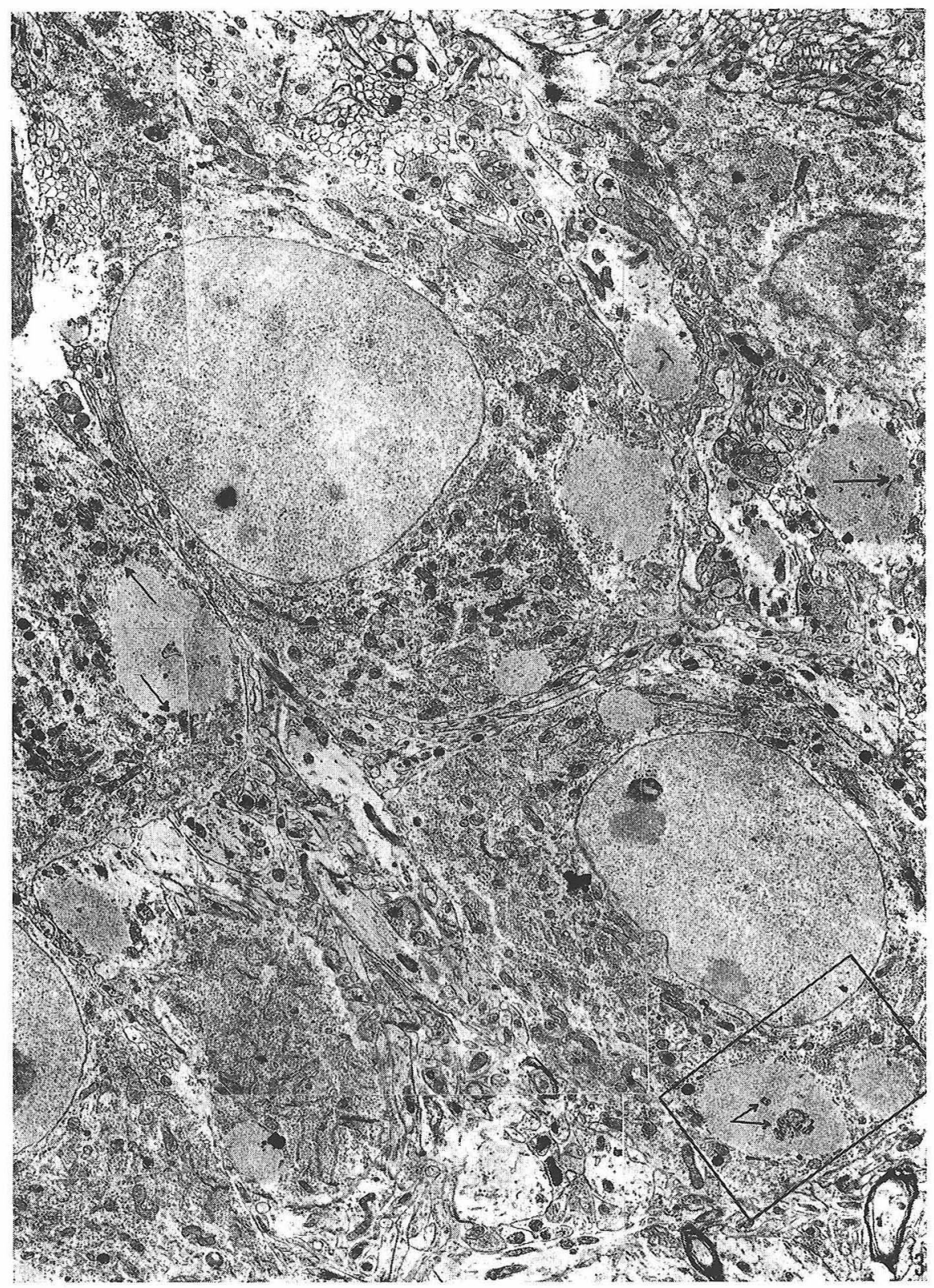

Fig. 3. A considerable number of Negri bodies as in Fig. 2. Elongated virus particles are found within and contiguous to the Negri bodies (arrows). X 3,400 


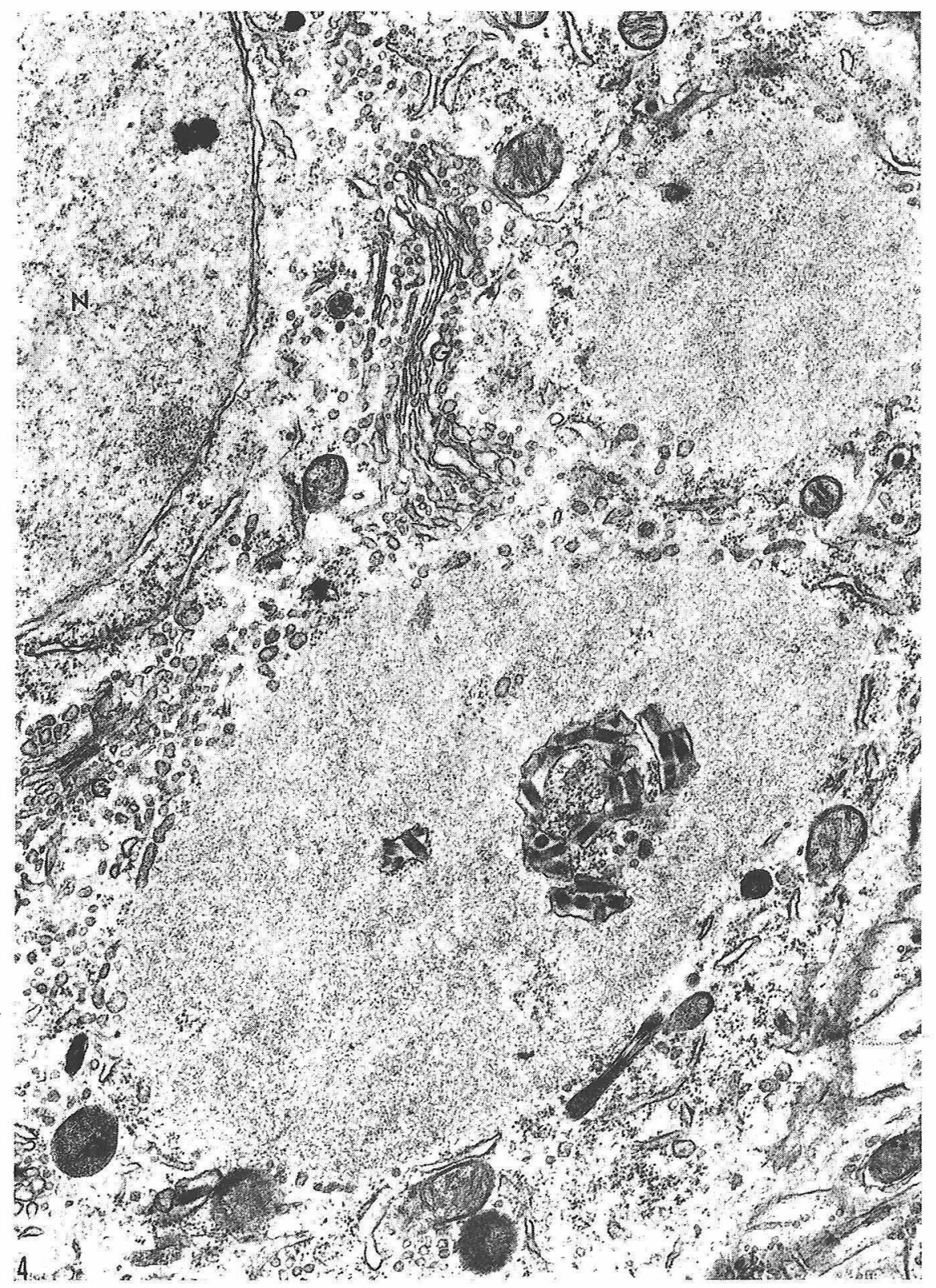

Fig. 4. A higher magnification of the electron micrograph showing two Negri bodies within the rectangular area shown in Fig. 3. Negri bodies are composed of fnely fibrillar and granular substance. The typical inner bodies can be found within the Negri body. Note the row of vesicles containing electron opaque material linking Golgi cisternae with the Negri body. $\mathrm{N}$; nucleus, G; Golgi complex. X 20,000 


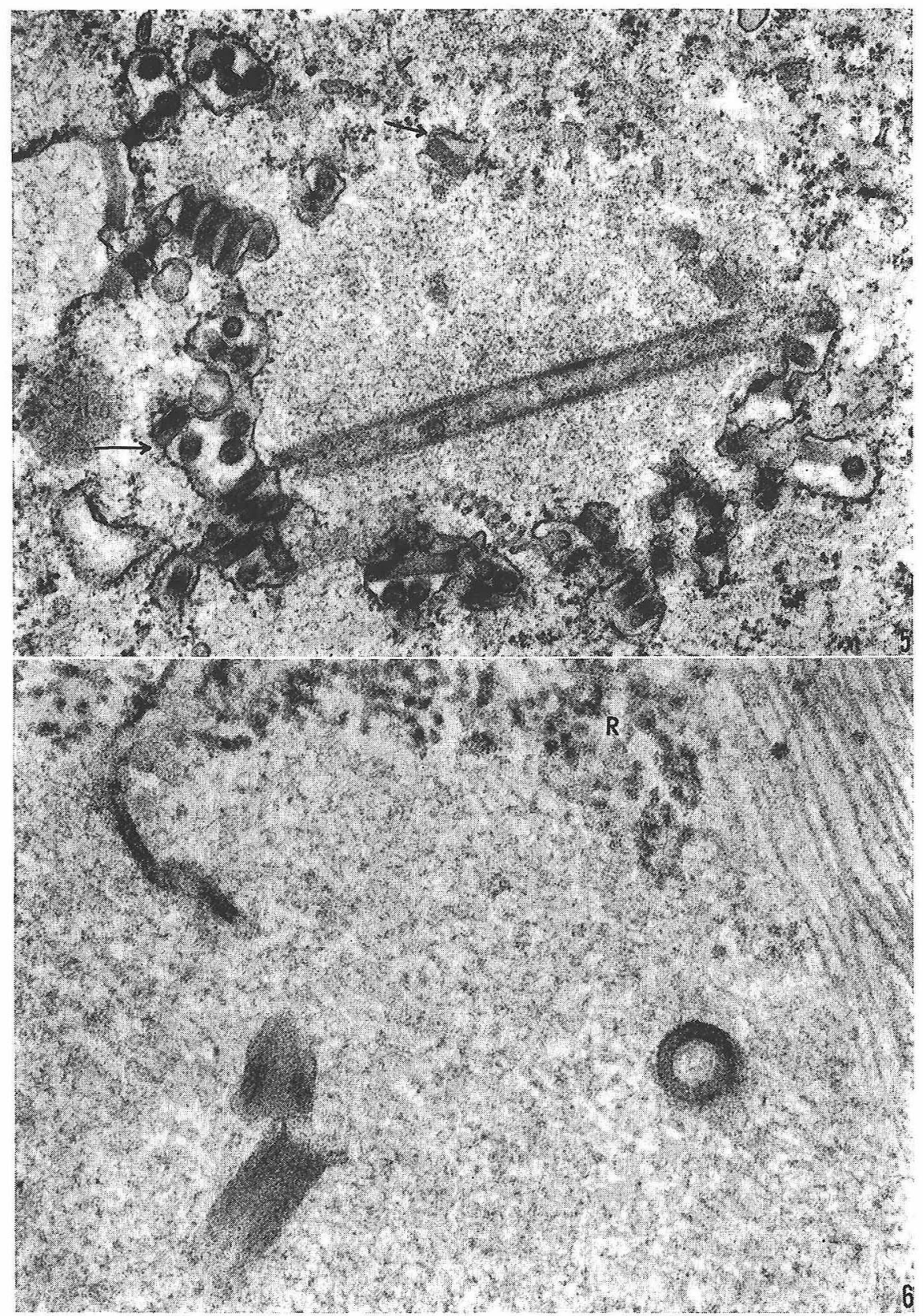

Fig. 5. A part of a nerve fiber around the hippocampus. The Negri body contains one single-membraned particle (the first type) and a number of double-membraned rods (the third type) are packed within the lumen of the endoplasmic reticulum around the Negri body. The outer membranes of certain particles (arrows) are connected to the membranes of the endoplasmic reticulum. $\quad \mathrm{X} 36,800$

Fig. 6. A part of a Negri body within the nerve cell around the hippocampus. Two double-membraned particles (the second type) in longitudinal-section are found and a particle in cross-section clearly shows the third inner membrane. R; ribosme. X 84,800 


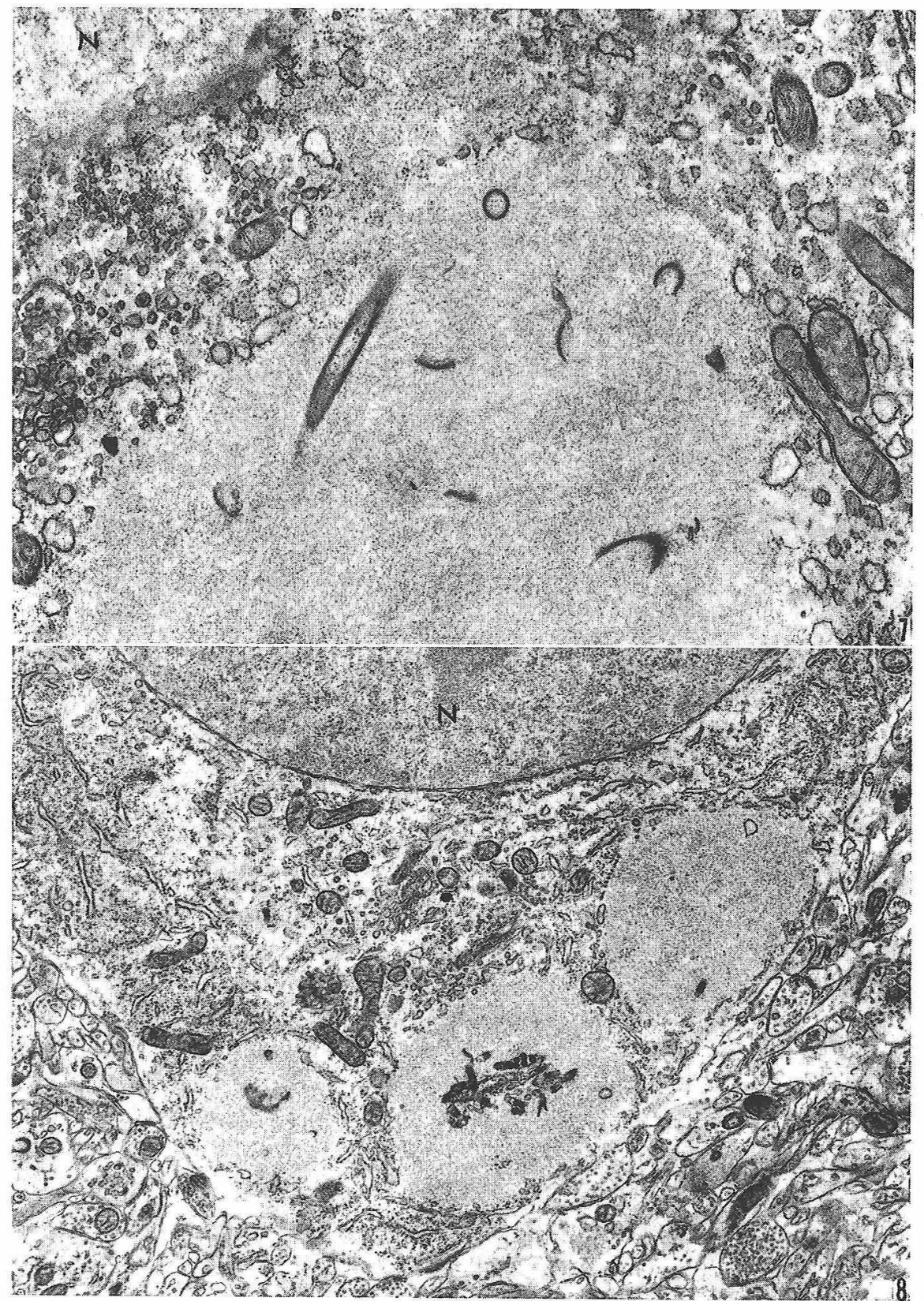

Fig. 7. A part of a nerve cell found around the hippocampus. Double-membraned structures in various plane are seen within the Negri body, two of which are similar in appearance to the second type particle. $\quad \mathrm{N}$; nucleus. X 19,000

Fig. 8. Three small Negri bodies located near by each other. The middle one contains the typical inner body. One particle of the second type is also found within the right Negri body. $\quad \mathrm{N}$; nucleus. X 9,500 

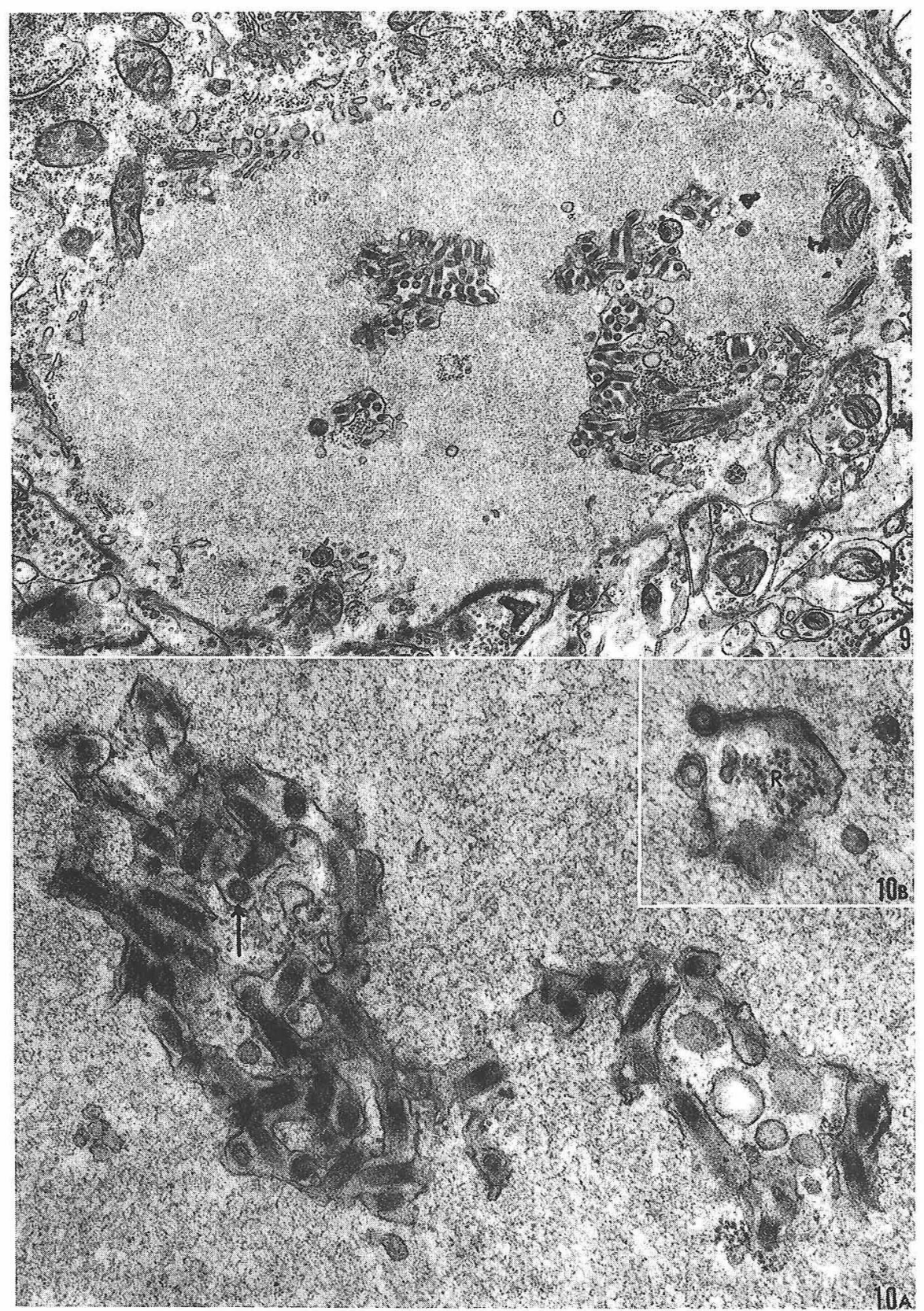

Fig. 9. A large Negri body within a nerve cell. Its outline is highly irregular and a part of the cytoplasm appears to be invaginated into the Negri body. Inner bodies are also seen. within it. X 12,400

Fig. 10. A part of a Negri body. A) A typical inner body at higher magnification. Both some amount of the cytoplasm and a number of particles within the lumen of the endoplasmic reticulum are surrounded by the ground substance of the Negri body. These particles are similar in appearance to particles of the third type in Fig. 5. An, arrow shows a particle clearly demonstrating the double membranous structure in cross-section. $\quad \mathrm{X} 35,600$

B) The particle in cross-section is assumed to belong to the second type, but the outer membranes are connected at two points to the double membranes running parallel, which are continuous with the cytoplasmic ground substance. $\mathrm{R}$; ribosome. $\mathrm{X} 38,300$ 


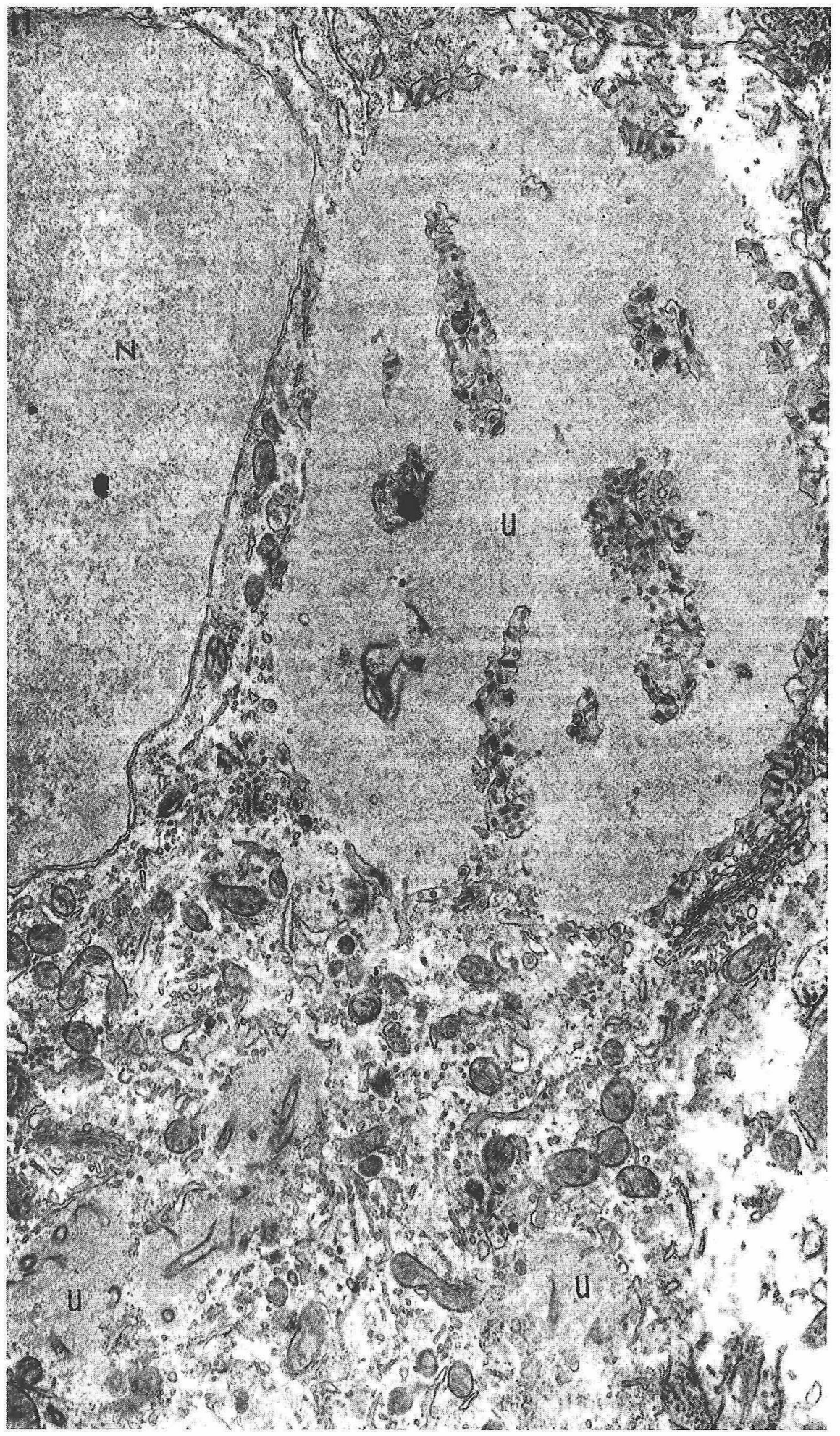

Fig. 11. Both the large Negri body showing some semicircular swellings and a clump of small Negri bodies are present within the same nerve cell. Small Negri bodies contain a number of double-membraned structures varying in shape and being similar to particles of the second type. Within a large Negri body, several inner bodies are seen and one of them is connected with the cytoplasmic area around the Negri body. $\mathrm{N}$; nucleus, $\mathrm{n}$; Negri body $\mathrm{X} 11,900$ 


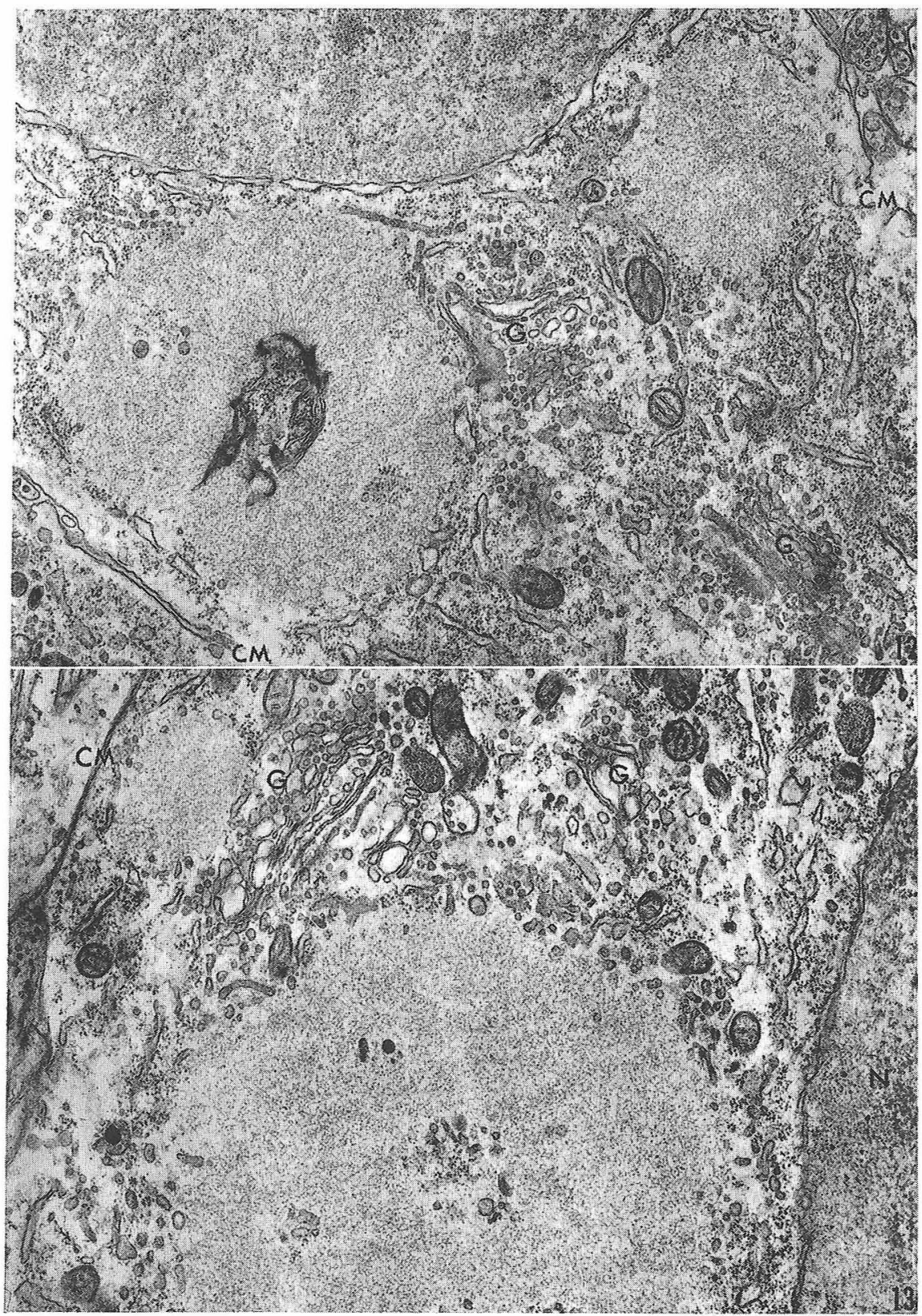

Fig. 12. Well developed Golgi complexes near the Negri body. Note an increase in number of small vesicles between the Negri body and the Golgi cisternae. These small vesicles contain electron opaque material. G; Golgi complex, CM; cell membrane. X 15,700

Fig. 13. Numerous small vesicles surround a Negri body in close association with the Golgi cisternae. $\mathrm{N}$; nucleus, $\mathrm{G}$; Golgi complex, CM; cell membrane $\mathrm{X} \mathrm{16,200}$ 
しかし, 超薄切片作製に至る複雑な操作の為に人工産物 が多く, その電顕像は今一つの鮮明さを欠き, その構造 を精しく記載するには至らなかつた。 最近, 松本 (1962, 1963) 20021) は狂犬病街上毒ウイルス感染マウス 脳安門角 を電顕形態学的に検索し, 細胞内ウイルス像を明かにす ると共に, 該ウイルス増殖と密接な形態学的関連を持つ マトリックス域がネグリ小体形成能に関係なく常に感染 細胞に出現するという知見を得た。この事実から，ネグ リ小体がマトリックス域と同一構造物ではなく，寧ろ ウイルス粒子を含まず種々の複雑な形態を示す細胞質内 封入体 (dense body) である可能性を示唆した. その後 のわれわれの検索もほぼこの考察に沿つて写真を撮影し て行つた. 一方, ネグリ小体形成能を欠除した固定毒ウ イルス感染細胞においても，ウイルス増殖と関連して同 一形態を示すマトリックス域の出現が報告された ${ }^{773334)}$. かくて諸家の電顕形態学的知見より，ネグリ小体の本態 はウイルス増殖部位とは別個の，寧ろウイルス感染に基 づく細胞二次産物と見做すべき可能性が強調されるに至 つた。しかし，所謂 dense body は神経細胞よりは寧ろ 神経膠細胞と同定される細胞内に出現する傾向の多いこ とが明かになって来た ${ }^{22}$. 従つて, 最終的結論にはさら に慎重な検討が必要となつた。

われわれはネグリ小体の電顕形態学的検索に際し, 特 に慎重な考慮を払つた。すなわち, 電顕的に脳組織の部 位同定を容易ならしめる為, 特徽的な神経細胞配列を示 しかつ同小体好発部位である安門角神経細胞層を検索対 象とした.さらに予め光顕的に確認した同小体と同一構 造物を直接電顕下に観察する為, 既報 25$)$ のごとく Epon 包埋ブロックより超薄切片㧍よびこれに連続する $1 \mu$ 切 片を作製した. $1 \mu$ 切片に各種の含エオジン染色を試み たが，Epon 包埋剤がこれ等色素と組織との親和性を阻 害するためか，包埋組織を染め得なかつた。しかし， toluidine blue 染色により淡染性細胞質内封入体が明瞭 に認められた (第 2 図)。従つて, ネグリ小体の本態を電 顕形態学的に論ずる場合, これ等細胞質内封入体がネグ リ小体(第 1 図) と同一構造物であるか否かがまず決定さ れるばならない，第 2 図が第 1 図と同じく安門角神経 細胞層を示すことは明かである。両切片（第 1 および 2 図）を比較した場合，ネグリ小体(第 1 図)㧍よび細胞質 内封入体 (第 2 図) は両切片の厚さの相違を考慮してもそ れぞれの出現頻度は両者においてよく一致し, かつ殆ん ど全ての神経細胞内に認められる。しかも，各神経細胞 にはこれ等構造物以外飞何らの病理形態学的変化も認め 得なかつた。一方，ネグリ小体周囲に明瞭な halo が見 られる(第 1 図)にも拘らず, $1 \mu$ 切片に斯る構造は認め られない。しかし，これ等 halo はアルコール固定に際
乙顕著に 認めるが，Zenker 氏固定液使用の場合 halo の出現が減少するので該構造は固定に際し生じた人工産 物と見做し得る. 以上の点を考慮すれば， $1 \mu$ 切片に認 められる toluidine blue 淡染性細胞質内封入体 (第 2 図) はエオジンで染色し得なかつたが，パラフィン切片に見 られるネグリ小体(第 1 図) と形態学的に同一構造物と考 え得る. 斯る同定に立脚し $1 \mu$ 切片 (第 2 図) に連続する 超薄切片を電顕形態学的に検索した。 低倍率電顕地図 (第 3 図)において細胞質内封入体(第 2 図) は中等度の電 子密度を持つた均一な領域として認め得るが, 高倍率電 顕写真(第 4 図)上り該領域は細顆粒状ないし細線維状基 質上り構成され，狂犬病感染細胞において諸家 2)7713320) 21334)の報ずるマトリックス域と同一の構造を示す。従つ て, ネグリ小体の好酸性基質はウイルス感染に基づく細 胞変性産物ではなく, ウイルス増殖の場そのものである と結論し得る. 斯る知見に基づき, 以後の記載に際し, 本研究で認められるマトリックス域をその大きさに関係 なく全てネグリ小体と記す.

一方, ネグリ小体の 重要な 構成因子である innere Körperchen が同小体内部で種々の分布を示し，かつそ の数が同小体の大きさと関連することは古くより知られ ている. 従つて, Epon 包埋 $1 \mu$ 切片に認められる細胞質 内封入体内部の toluidine blue 濃染性顆粒構造 (第 2 図) は形態学的に innere Körperchen に該当するものと考え 得る. 既報25)のごとく, 電顕的 innere Körperchen はネ グリ小体内部でその基質と劃然と区別された領域で小胞 体と密接な形態学的関連性を示す而型粒子および細胞質 成分より構成される(第 $3 ， 4 ， 8 \sim 11$ 図). $1 \mu$ 切片に見 られる innere Körperchen が連続する超薄切片で認めら れなかつたり，その逆の関係の場合に遭偶した（第 2,3 図の比較). 斯る形態学的相違は両切片の厚さの差によ るもので, innere Körperchen が種々の容積を持つ為で あろう. 従つて電顕的 innere Körperchen は上記構造の 他，III型粒子が認められず細胞質成分のみ（第 $12 ， 13$ 図）より構成される等種々の形態を示すものと考えられ る. innere Körperchen の toluidine blue 濃染性が本質 的にウイルス粒子あるいは細胞小器官の何れによるもの か断定し難い.

本研究は 動物実験である為に 感染の同時性は期待さ れず，従つて安門角神経細胞層に出現するネグリ小体 は種々の発達段階を表現するものと思われる。一般に 小型ないし中型ネグリ小体法 同一細胞内で散在性（第 3 図）あるいは互に隣接して（第 $4 ， 8 ， 12 ， 13$ 図）見 られる比較的規則的な円形ないし棈円形を示すと共に innere Körperchen の数は少ない，一方，大型ネグリ小 体は不整形でかつ多数の innere Körperchen を创含する 
(第 9，11図). 斯る点を考慮すれば, innere Körperchen の形成様式はネグリ小体の発達過程と関連づけて考える のが妥当と思える。 innere Körperchen に見られる粒子 は全て II 型粒子で小胞体との形態学的関係はネグリ小体 外側周辺部のウイルス粒子像と本質的に同一であり（第 $5,10_{\mathrm{A}}$ 図), さらに innere Körperchen 内にリボゾーム 顆粒あるいは小胞体等の細胞質成分を含有し（第 4, 8 13 図)，時には糸粒体を認めた. Dales(1963) ${ }^{5)}$ はワクチ ニア・ウイルス感染細胞を電顕オートラジオグラフィー 法で検索し，マトリックス域が感染ウイルス DNA の放 出部位に一致して出現することを示唆した。これは，ウ イルス感染に基づくマトリックス域の形成が細胞質の一 微小局所で細胞質から独立した領域として出発すること を示唆すると思われる。もし同様の現象が狂犬病ウイル ス感染細胞においても生じ得るならば, 第 $4,8,12$ およ び 13 眓に見られるネグリ小体はそれぞれ互に別個のウ イルス初期感染巣より発達し来たつたものと見做し得る であろう。斯る観点に立てば，大型ネグリ小体の形成が 終局的には互に隣接しかつ独立して発達し続けた数個の ネグリ小体の癒合の結果生じ，また innere Körperchen はその際に周囲細胞質が包み込まれて形成される可能性 を考え得る.第 9 および 11 図に見るごとく,大型ネグリ 小体に屡々半円形突出部の存在すること, さらに innere Körperchen と該域周囲細胞質に連続性の認められるこ とは上記可能性を支持するものと思われる. Fernandes 等 $(1963)^{8)}$, Wiktor 等 (1964) ${ }^{41)}$ あるいは大谷 $(1965)^{30)}$ は固定毒ウイルス感染培養細胞あるいは街上毒ウイルス 感染神経細胞に螢光抗体法を用い，感染初期の細胞質内 に多数の小型螢光顆粒を認めたが, 感染培養細胞の継代 によりこれ等小型螢光顆粒が大型顆粒に置き換ることを 認めている。ネグリ小体が螢光陽性であることを示した Goldwasser 等 (1958) 9)の業績を考慮すれば，この事実は また小型ネグリ小体の癒合を支持している様にも考えら れる。

安門角神経細胞層に出現するネグリ小体と関連して認 められるウイルス粒子は主として II型粒子で（第 4, 8〜 11図)，これら粒子の形態は Roots 等 (1963) 34) および Johnson 等 (1964) ${ }^{13)}$ が固定毒ウイルス感染脳で報じた粒 子と形態学的に一致する。一方, I 型およびII 型粒子あ るいは二重膜構造小片は小型ないし中型ネグリ小体に認 められるものの様であるが(第 8,11 図), 安門角皮質神経 細胞あるいは神経線維では比較的容易に見出し得た（第 5，6，7図).しかしこの場合，ネグリ小体は一般に小型 ないし中型であつた。これら三種類の粒子の相互関係は 現在想像の域を出ない.かれわれは既報22)のごとく， I 型粒子より III型粒子への移行の可能性を両者の形態学的
関連性より考慮した. 第 $10 \mathrm{~B}$ 図に見られる横断面粒子は 明かに三重膜構造を持ち, 最外側膜と中間膜の閒の電子 密度が高く川型粒子の性格を持つに拘らず, 最外側膜が. 2 力所で互に平行した膜構造に移行し, その一端は細胞 質に連る。従つて, 内部の残る二重膜で而型粒子を形成 する可能性を示唆するものである. しかしながら，一般 にII型粒子はネグリ小体周辺部のIII型粒子に比し量的に 余りにも少なく見出される. しかも固定毒ウイルス感染: 脳に㧍いてはIII型粒子のみが見出された ${ }^{13) 14)}$. 従つて,

I 型およびI型粒子の出現がウイルス株の差による可能 性も考慮されなければならない，一方既述のごとく，I 型およびI型粒子あるいは二重膜構造小片は一般に小型 ないし中型ネグリ小体に認めら机（第 5〜8, 11 図），安 門角神経細胞層には稀である。この知見より，I 型およ びII 型粒子の出現が宿主細胞の機能と関係したネグリ小 体の発育段階と密接に関連する可能性も考慮されねばな. らないであろう。

Goodpasture (1925) ${ }^{10)}$ は街上毒ウイルス 感染家兔脳で innere Körperchen を包含せぬ多数の小型好酸性封入体 を神経細胞細胞質内に認めこれらをLyssa body と命 名しネグリ小体と厳密に区別した. 電顕形態学的には, 第 3,12 および13図に見られるごとく innere Körperchen. の存在しないネグリ小体も認めるが，超薄切片の場合ネ グリ小体の一断面を示すに過ぎない。しかし一般に小型 ないし中型ネグリ小体では innere Körperchen が小さい 傾向を認めた. Wolman 等(1952) ${ }^{44)}$ は街上毒ウイルス感 染マウス脳を経時的に組織化学的検索を行つた際, ネグ. リ小体より Lyssa body への移行を主張した. しかし, われわれの観察では感染神経細胞内に出現する大小種々 のネグリ小体が唯一の病的所見であり, innere Körperchen を含むものも含まないものも全て質的には同一の 基質から成りたつている。また，Goldwasser 等(1958)92 は螢光抗体法による観察で, ネグリ小体以外に，同小体 特殊染色法で好酸性を示す小型封入体が螢光陽性である ことを認めた。斯る知見より，ネグリ小体および Lyssa body は狂犬病ウイルス感染に際し特異的に出現する封 大体として共に本質的には同一構造物であると考えられ る.

以上のごとく，ネグリ小体の主要部を構成する好酸性: 基質がウイルス増殖と密接な関連を持つことが明かとな つた. この知見は螢光抗体法によりネグリ小体にウイル ス抗原の存在することを示した Goldwasser 等(1958) ${ }^{9)}$ の結果を支持するものの様である. 一方, 同小体を形成 しない街上毒211および固定毒7)1334) ウイルス感染細胞に 同一形態を示すマトリックス域が認められた. 従つて, 狂犬病ウイルスは全てネグリ小体形成能を持たねばなら 
ないことにもなる. しかるに衆知のごとく，固定毒ウイ ルスは殆んど例外なく同小体形成能を欠除し，街上毒ウ イルスにおいてさえその形成能に著しい差異が認められ る訳で，われわれの得た知見と矛盾する.われわれは光 顕で識別し得ない小型ネグリ小体の出現を屡々経験して いる(第 2，3 図の比較)。一方，Goldwasser 等(1958) ${ }^{92}$ は固定毒ウイルス感染脳に螢光抗体法を用い，多数の螢 光陽性顆粒を認めたが，これ等顆粒は全てネグリ小体に 該当する大型螢光顆粒に比し小型であると報じた。従つ て, 固定毒ウイルス感染脳では形成されるマトリックス 域が小型に止まる為にネグリ小体として光学顕微鏡で認 め得ないということになろう。この疑問は狂犬病ウイル スの固定毒化に伴い，何故大型マトリックス域が形成さ 狆得なくなるのかといら課題に置き換えられるであろ う.

神経細胞は通常ニ゙ルジ体の発達が良好で (第 3 図), 屢 トネグリ小体周辺部に認められ，時にはゴルジ囊および 空胞の拡大, さらにゴルジ小胞の増加が認められた（第 4, 12, 13 図). 一方, lysosome の基本構造と見做す心゙ き pure lysosome ${ }^{29)}$, proto-lysosome ${ }^{11)}$ るいは virgin lysosome ${ }^{26)}$ がゴルジ小胞に該当することが電顕組織化学 的に明かにされつつある. Gordon 等(1965)11) は細胞の 食喰作用と関連してゴルジ小胞の増加を認めた. 斯る知 見は細胞の貪喰作用あるいは自己消化作用におけるゴル ジ小胞と lysosome 賦活化の密接な関係を示唆するもの であろう。 ネグリ小体含有細胞に変性像を認めず, 後報 するごとく固定毒ウイルス感染神経細胞に強い変性像の 認められる点を考慮すれば，固定毒ウイルス 感染の場 合, 神経細胞の lysosome が何らかの原因で急速に賦活 され広汎な自己消化作用を惹起する結果, 細胞変性を来 し大型マトリックス域を形成し得ないのではなかろう か. ネグリ小体の本態が判明した現在, 神経細胞, 特に 安門角神経細胞層における街上毒および固定毒ウイルス の増殖像を電顕形態学的に比較し, さらに電顕組織化学 的方法を併用することによりネグリ小体形成能と神経細 胞内反応様式との関係をさらに詳細に明かにし得るもの と考えられる。

\section{V. 結 論}

1. 狂犬病街上毒ウイルス感染マウス脳より安門角神 経細胞層を含む超薄切片およびこれに連続した $1 \mu$ 切片 を作製し，ネグリ小体の形態に就いて電子顕微鏡および 光学顕微鏡による比較観察を行なつた.

2.ネグリ小体は toluidine blue 染色 $1 \mu$ 切片におい て淡染性細胞質内封入体として認められ，これに連続す る超薄切片による電顕像は同小体好酸性基質がウイルス
増殖と密接な関係を持つマトリックス域であることを明 かにした。

3. ネグリ小体の重要な構成因子である innere Körperchen は $1 \mu$ 切片において濃染性顆粒構造として認め られるが，その電顕像はマトリックス域内部で該域基質 と劃然と区別して認められる領域を示し，小胞体と関連 したウイルス粒子(III型粒子)およびリボゾーム顆粒等の 細胞質成分より構成される.

4. innere Körperchen は大型マトリックス域形成過 程で小型マトリックス域の癒合に際し, 該域周囲細胞質 が包み込まれることにより形成されるものと思われる.

5. 従つて, innere Körperchen は本質的に細胞質成 分と考えられるが，その好塩基性がウイルス粒子あるい は細胞質成分のいずれによるか判然としなかつた。

6. ネグリ小体形成能は宿主細胞内反応と関連したマ トリックス域の大きさおよびその出現頻度と密接に関係 するものと思われる。

本研究は文部省科学研究費の援助を受けた。

最後に御指導, 御校閲を得た松本清一教授に哚謝する。

\section{Abstract}

Brains of mice infected with the street rabies virus were observed by the electron microscope and by the light microscope for aiming to elucidate the origin of the Negri body. Adjacent thin (ca $0.05 \mu$ ) and thick (ca $1.0 \mu$ ) sections were prepared from Epon embedded blocks of the nerve cell band of Ammon's horn in the hippocampus where Negri bodies are apt to be abundant and by mapping the sections could be identified the same nerve cells including Negri bodies under both electron and light microscope.

The Negri bodies were recognizable by light microscopy as lightly colored cytoplasmic inclusions containing few dark granules after toluidine blue staining. Electron micrographs of the consecutive sections revealed that the ground substance of the Negri body was identical with the matrix which was commonly related to rabies virus replication of both street and fixed strains. This evidence follows the conclusion that the degree of capability to produce Negri bodies depends upon the formation of numerous and extensive foci of virus synthesis.

It might appear that Negri bodies increase in their volume by coherence of neighbouring small Negri bodies within the same cytoplasm, resulting in varied positions of inner bodies within large Negri bodies. The inner body, an important constituent of the Negri body, being surrounded by the ground substance of this inclusion was composed of virus particles? associated with some amount of cytoplasmic constituents. 


\section{文 献}

1) Acton, H. W., and Harvey, W. F. (1911): The nature and specificity of Negri bodies. Parasitology 4,255-272. - 2) Atanasiu, P., Lépine, P., Sisman, J., Eauguet, C., and Wetten, M. (1963): Étude morphologique du virus rabique des rues en culture de tissu. Compt. Rend. Acad. Sc. 256, 3219-3221. -3) Babes, V. (1907): Untersuchung iber die Negrischen Körper und ihre Beziehung zu dem Virus der Wutkrankheit. Z. Hyg. u. Infektionskrankh. 56, 435-452. - 4) Covell, W. P., and Canks, W. B. C. (1932): Studies on the natire of the Negri body. Amer. J. Path. 8, 557-572. -5) Dales, S. (1963) : The uptake and development of vaccinia virus in strain $\mathrm{L}$ cells followed with labeled viral deoxyribonucleic acid. J. Cell Biol. 18, 51-72. - 6) D'Amato, L., and Faggella, V. (1910): Negrische Körper Lentzsche Körper und Veränderungen der nervösen Zentren in der Wutkrankheit. Z. Hyg. u. Infektionskrankh. 65, 353-368.-7) Davies, M. C., Englert, M. E., Sharpless, G. R., and Cabasso, V. J. (1963): The electron microscopy of rabies virus in cultures of chicken embryo tissues. Virology 21, 642-651. - 8) Fernandes, M. V., Wiktor, T. J., and Koprowski, H. (1963): Mechanism of the cytopathic effect of rabies virus in tissue culture. Virology 21, 128-130. - 9) Coldwasser, R. A., and Kissling, R. E. (1958) : Fluorescent antibody staining of street and fixed rabies virus antigens. Proc. Soc. Exp. Biol. and Med. 98, 219-223. - 10) Coodpasture, E. W. (1925) : A study of rabies, with reference to a neural transmission of the virus in rabbits, and the structure and significance of Negri bodies. Amer. J. Path. 1, 547-582. - 11) Gordon, G. B., Miller, L. R., and Bensch, K. G. (1965): Studies on the intracellular digestive process in mammalian tissue culture cells. J. Cell Biol. 25, No 2, Part 2, 41-55. - 12) Hottle, G. A., Morgan, C., Peers, J. H., and Wyckoff, R. W. C. (1951) : The electron microscopy of rabies inclusion (Negri) kodies. Proc. Soc. Exp. Biol. and Med. 77, 721-723. - 13) Johnson, R. T., and Mercer, E. H. (1964) : The development of fixed rabies virus in mouse brain. Aust. J. exp. Biol. med. Sci. 42, 449-456. -14) Lentz, O. (1909) : Ueber spezifische Veränderungen an den Ganglienzellen wut- und staupekranker Tiere. Ein Beitrag zu unserem Kenntnissen aber die Bedeutung und Entstehung der Negrischen Körperchen. Z. Hyg. u. Infektionskrankh. 62, 63-94. - 15) Levaditi, C., Nicolau, S., and Schoen, R. (1924): La microsporidiose du lapin; ses relations avec la rage. Compt. Rend. Acad. Sc. 178, 256-258. - 16) Levaditi, C., Nicolau, S., and Schoen, R. (1926) : Recherches sur la rage. Ann. Inst. Pasteur 40, 973-1069. - 17) Lipschütz, B. (1919) : Ueber Chlamydozoa-Strongyloplasmen. II. Ueber den Bau und die Entstehung der "Zelleinschlüsse". Wien. klin. Wsch. 32, 1127-1131. - 18) Luft, J H. (1961) : Improvements in epoxy resin embedding methods. J. Biophysic. and Biochem. Cytol. 9, 409-414. - 19) Massignani, A. M., and Malferrari, R. (1961): Phosphotungstic acid-eosin combined with hematoxylin as a stain for Negri bodies in paraffin sections. Stain technol. 36, 5-8. - 20) Matsumoto, S. (1962): Electron microscopy of nerve cells infected with street rabies virus. Virology 17, 198-202. - 21) Matsumoto, S. (1963) : Electron microscope studies of rabies virus in mouse brain. J. Cell Biol. 19, 565-591. - 22) 松本清一, 宮本包厚 (1965): 狂犬病ウイルスの形態・細胞化学シンポジウ ム，第 15 集，179-191，日本細胞化学会，丸羓株式会 社 - 23) Millonig, G. (1961): B. 26. Advantages of a phosphate bufferfor $\mathrm{OsO}_{4}$ solutions in fixation. J. Applied Physics 32, 1637. - 24) Milloning, G. (1961): A modifiedprocedure for lead staining of thin sections. J. Biophysic. and Biochem. Cytol. 11, 736739. - 25) Miyamoto, K., and Matsumoto, S. (1965) : The nature of the Negri body. J. Cell Biol. 27, 677682. - 26) Moe, H., Rostgaard, J., and Behnke, O. (1965): On the morphology and origin of virgin lysosomes in the intestinal epithelium of the rat. J. Ultrastruct. Res. 12, 396-403. - 27) Muratowa, A. P. (1934): Ueber die Morphologie des Lyssavirus. Zentr. Bakt. 132, 65-77. - 28) Negri, A. (1903): Beitrag zum Studium der Aetiologie der Tollwuth. Z. Hyg. Infektionskrankh. 43, 507-528. -29) Novikoff, A. B. (1963): Lysosomes in the physiology and pathology of cells: contribution of staining methods. Ciba Found. Symp. Lysosomes. p. 36-77. Churchill, London. - 30) 大谷杉士 (1965) : 私信 - 31) Prowazek, S. (1907): Chlamydozoa I. Zusammenfassende Uebersicht. Arch. f. Protistenkunde 10, 336-358. - 32) Reagan, R. L., and Brueckner, A. L. (1950) : Electron micrographs of Negri bodies found in rabies. J. Inf. Dis. 87, 213-216. - 33) Remlinger, P. (1903): Le passage $\mathrm{du}$ virus rabique a travers les filtres. Ann. Inst. Pasteur 17, 834-849. - 34) Roots, E., and Schultze, I. (1963): Neuere elektronenmikroskopische Befunde an Gehirnen nach Infektion mit Tollwutvirus. Zentr. Bakt. I Ord. 188, 159-173. - 35) Shortt, H. E. (1935): Morphological studies on rabies. Part II. Negri bodies in the hippocampus major in street virus infections. Indian J. Med. Res. 23, 407-436. - 36) Sourander, P. (1956) : Cytochemical studies on rabies inclusions (Negri body). J. Path. Bact. 72, 257-265. - 37) Ssawatezew, A. I., and Ssiderew, N. W. (1929): Zur Morphologie der Negrischen Körperchen. Zentr. Bakt. 113, 425-428. - 38) Trump, B. F., Smuckler, E. A., and Benditt, E. P. (1961): A method for staining epoxy section for light microscopy. J. Ultrastruct. Res. 5, 343-348. - 39) van Rooyen, C. E., and Rhodes, A. J. (1948): 
Virus disease of man. 2 nd ed. p. 835-843. New York, Thomas Nelson \& Sons. - 40) Volpino, G. (1906) : Ueber die Bedeutung der in den Negrischen Körpern enthaltenen Innenkörperchen und ihren wahrscheinlichen Entwickelungsgang. Zentr. Bakt. (Ref.) 37, 459-463. - 41) Wiktor, T. J., Fernandes, M. V., and Koprowski, H. (1964) : Cultivation of rabies virus in human diploid cell strain WI-38. J. Immunol. 93, 353-366. - 42) Williams, A. M., and
Lowden, M. M. (1906) : The aetiology and diagnosis of hydrophobia. J. Infect. Dis. 3, 452-483. - 43) Wolman, M., and Behar, A. (1952): Cytochemical evidence for the nature of herpes simplex inclusion bodies. J. Infect. Dis. 91, 63-68. - 44) Wolman, M., and Behar, A. (1952): A cytochemical study of the nature of Negri bodies. J. Infect. Dis. 91, 69-71. 